\title{
С. В.Куликов
}

\section{ФЕВРАЛЬСКАЯ РЕВОЛЮЦИЯ СПУСТЯ СТО ЛЕТ}

В статье рассматривается проблема соотношения факторов организованности и стихийности накануне и во время Февральской революции 1917 г. В отличие от предшественников автор полагает методологически неверным противопоставлять эти факторы друг другу, поскольку при любой революции они присутствуют одновременно. Причиной трактовки Февральской революции как исключительно стихийной, по мнению автора, является искусственное разведение понятий «заговор», «переворот» и «революция», которые в действительности являются этапами актуализации целостного феномена. Февраль 1917-го стал результатом деятельности Центрального военно-промышленного комитета и его Рабочей группы и был и заговором, и переворотом, и революцией, представляя собой симбиоз организованности и стихийности. Замалчивание вождями Февральской революции ее организованного характера объяснялось политическими причинами, прежде всего - необходимостью использования мифа о стихийности для легитимации республиканского строя. Впоследствии советская историография обращала особое внимание на действия большевиков, а зарубежная историография - на деятельность небольшевистских социал-демократических групп. В данной статье впервые в историографии особое внимание уделяется аффилиациям Рабочей группы Центрального военно-промышленного комитета. Именно эти аффилиации, совместно с больничными кассами и профсоюзами, при самом активном участии рабочих кооперативов, контролировавшихся Рабочей группой Центрального военно-промышленного комитета, и подготовили, с ведома руководителей ЦВПК А.И. Гучкова, А. И. Коновалова и М.И. Терещенко, то массовое рабочее движение, которое вышло на улицы Петрограда 23 февраля 1917 г., а затем получило развитие в дальнейших уличных манифестациях. Пик этого движения, военное восстание 27 февраля 1917 г., был срежиссирован все тем же внепартийным центром, возглавляемым А. И. Гучковым. Именно он, используя методы массового и индивидуального давления на монарха, принудил его к отречению в пользу не сына, наследника-цесаревича Алексея Николаевича, а брата, великого князя Михаила Александровича. Данное обстоятельство способствовало сохранению компромисса между монархистами и республиканцами, который обеспечил победу революции. Библиогр. 82 назв.

Ключевые слова: Центральный военно-промышленный комитет, Рабочая группа, заговор, переворот, революция, организованность, стихийность.

Для цитирования: Куликов С. В. Февральская революция спустя сто лет // Вестник СанктПетербургского университета. История. 2017. Т. 62. Вып. 3. С. 545-559. DOI: 10.21638/11701/ spbu02.2017.307

\section{S. V.Kulikov}

\section{THE FEBRUARY REVOLUTION A HUNDRED YEARS LATER}

The article discusses the problem of correlation between factors of organization and spontaneity before and during the February revolution of 1917. Unlike his predecessors, the author believes it methodologically incorrect to oppose these factors to each other, as in any revolution they are present at the same time. The reason for interpretations of the February revolution as a purely natural event, according to the author, is the artificial comingling of the concepts of "conspiracy", "coup" and "revolution", which in reality are the stages of mainstreaming a holistic phenomenon. February 1917 was the result of the activities of the Central Military-Industrial Committee (CMIC) and its Working Group

Куликов Сергей Викторович - кандидат исторических наук, старший научный сотрудник, Санкт-Петербургский институт истории Российской академии наук, Российская Федерация, 197110, Санкт-Петербург, Петрозаводская ул., 7; sergeykulkikov70@mail.ru

Kulikov Sergey Viktorovich - PhD in History, Senior Researcher, St. Petersburg Institute of History, Russian Academy of Sciences, 7, Petrozavodskaya str., 197110, St. Petersburg, 197110, Russian Federation; sergeykulkikov70@mail.ru

() Санкт-Петербургский государственный университет, 2017 
and was a conspiracy, coup and revolution, presenting a mixture of organization and spontaneity. The silence of the leaders of the February revolution as to its organized nature is explained by politics: first of all was the necessity of using the myth of spontaneity for legitimation of the republican regime. Subsequently, Soviet historiography has focused on the actions of the Bolsheviks, and foreign historiography on the activities of non-Bolshevik social democratic groups. In this article, for the first time in the historiography, special attention is devoted to the Working Group of the CMIC. It was these affiliations as a mass labor movement: relief funds for the sick and trade unions, and workers cooperatives controlled by the Working Group, that took to the streets of Petrograd on 23 February 1917 and then engaged in further street demonstrations. These cooperatives were prepared with the consent of the executives of the CMIC, A.I.Guchkov, A.I.Konovalov, and M. I. Tereshchenko. The peak of this movement, a military uprising on 27 February 1917, was organized by the same non-partisan center led by A.I. Guchkov. It was he, using methods of mass and individual pressure on the monarch, who forced the tsar to abdicate in favor of the Son of Tsarevich Alexey Nikolayevich, and of his brother, Grand Duke Michael Alexandrovich. This fact contributed to the preservation of a compromise between monarchists and republicans that ensured the victory of the revolution. Refs 82 .

Keywords: Central Military-Industrial Committee, a Working group, conspiracy, coup, revolution, organization, spontaneity.

For citation: Kulikov S. V. The February revolution a hundred years later. Vestnik of Saint Petersburg University. History, 2017, vol. 62, issue 3, pp. 545-559. DOI: 10.21638/11701/spbu02.2017.307

Вот уже без малого сто лет ведутся споры о том, чем была Февральская революция 1917 г. - заговором, переворотом или... революцией? Придание слишком серьезного значения семантической разнице между словами «заговор», «переворот» и «революция» объясняется свойственным российской историографии (а шире и массовому сознанию) словесным фетишизмом, при котором наименование какого-либо исторического явления превращается в некое священнодействие, когда наименование определяет именуемое, а не именуемое - наименование. В результате согласно российской семантической традиции слова «заговор» (конспирация»), «переворот» и «революция» воспринимаются иерархически: «заговор» (тайная деятельность узкого круга лиц по подготовке переворота) занимает низшую ступень иерархии (отсюда - пренебрежительное отношение к конспирологии), «переворот» (свержение заговорщиками правительства начиная с главы государства) среднюю, «революция» (замена одной формы правления и/или социально-экономической формации другими) - высшую. Представляется, однако, что в данном случае спор о Февральской революции - это не более чем спор о словах: действительно, всякая революция в своей основе имеет переворот, а за всяким переворотом стоит заговор. Хотя, с другой стороны, не всякий переворот заканчивается революцией («дворцовые перевороты» 1762 и 1801 гг., притом что первый из них современники называли «революцией», или «Третьеиюньский переворот»), и не всякий заговор завершается переворотом, точнее - удачным переворотом («заговор верховников», «заговор декабристов»).

Подразумевая слово «революция», Эдвард Люттвак писал: «Этот термин приобрел определенную популярность. Им были обозначены многие перевороты, так как считалось, что они были делом рук “народа”, а не нескольких заговорщиков». Давая определение «переворота», Люттвак, по сути дела, отождествил его не только с «революцией», но и с «заговором», поскольку подчеркивал, что «переворот», помимо прочего, «состоит в проникновении в государственный аппарат небольшой критически настроенной группы, которая использует его, чтобы устранить 
правительство от контроля над оставшейся частью госаппарата» [Люттвак 2012, c. 24, 26, 27]. Очевидно, что по принципу матрешки любая революция заключает в себе переворот, а переворот - заговор. Сами современники называли свержение романовской монархии и революцией, и переворотом [Зарин 1918, с. 4], в последнем случае - косвенно признавая ее заговорщические корни. Таким образом, исчезает сам предмет спора, и появляются возможности для выработки адекватного представления о Февральской революции, при изучении которой актуальна также дилемма о том, какой характер она имела - организованный или стихийный. В традиционной историографии организованность ассоциируется с «заговором» и «переворотом», а стихийность - исключительно с «революцией», хотя, учитывая точку зрения, обоснованную выше, противопоставление фактора организованности фактору стихийности методологически неверно, поскольку при любой революции оба эти фактора действуют если и не в равной мере, то одновременно, взаимно обусловливая и дополняя друг друга.

Если в настоящее время при изучении Февральской революции приходится уделять особое внимание фактору организованности, то только потому, что ранее он изучался явно недостаточно. Действительно, вся образовавшаяся за прошедшие сто лет историография этой революции делится на две неравные части: большинство историков, как отечественных, так и зарубежных, согласны, что она имела стихийный характер, явное меньшинство считает, что - организованный (конечно, в той или иной мере) [Хасегава 2014, с.60-70]. Между тем уже первый историк Февральской революции П.Н. Милюков еще в 1918 г. утверждал: «Из объективных фактов с бесспорностью вытекает, что подготовка к революционной вспышке весьма деятельно велась - особенно с начала 1917 г. - в рабочей среде и в казармах Петроградского гарнизона». При этом «закулисная работа по подготовке революции так и осталась за кулисами» [Милюков 2001, с. 39, 41]. В советской историографии до начала 1930-х годов Февральскую революцию рассматривали как стихийную, затем организаторами происходивших во время революции забастовок, демонстраций и вооруженных выступлений историки (прежде всего главный официальный историограф И.И. Минц [Минц 1977]) называли большевиков. Только Э.Н. Бурджалов показал, что к организации массовых волнений питерского пролетариата были причастны помимо большевиков и другие социалисты-интернационалисты - левые меньшевики, эсеры и «межрайонцы» [Бурджалов 1967]. Ц. Хасегава вслед за Э.Н.Бурджаловым признал, что волнения в Петрограде, будучи стихийными, в известной степени координировались упомянутыми социалистическими партиями [Hasegawa 1981]. М. Мелансон, отрицая стихийность Февральской революции, пошел дальше Э.Н. Бурджалова и Ц. Хасегавы, напрямую утверждая, что ею руководили социалисты-интернационалисты [Melancon 2000]. В эмигрантской историографии организованный характер Февральской революции трактовали в том смысле, что она - результат деятельности масонов [Кобылин 1998; Мельгунов 2003; Якобий 2005], позднее эта точка зрения перекочевала в работы западных [Катков 1997] и отечественных [Яковлев 1993; Старцев 2001; Брачев 2007, с. 7-236; Сафонов 2005, с.215-272] историков. Немногочисленные зарубежные и отечественные исследователи объясняли свержение монархии деятельностью не столько масонов, сколько германской агентуры в лице социалистов-интернационалистов, которых финансировала Германия [Катков 1997; Хереш 2004; Трауптман, Шиссер 
2004; Бъёркегрен 2007; Зееман, Шарлау 2007], либо - в конечном итоге - усилиями англо-саксонской агентуры (Великобритании и США) [Мультатули 2013]. А. Б. Николаев находит организаторов и руководителей Февральской революции в IV Государственной думе [Николаев 2002, 2005]. Наконец, Б.Н. Миронов органично свел воедино концепции о стихийном и организованном характере этой революции [Миронов 2010], а В.А. Никонов [Никонов 2016] подвел итоги предшествовавшей историографии Февраля 1917-го.

В качестве штаба по подготовке и проведению Февральской революции до сих пор особо не изучался Центральный военно-промышленный комитет, созданный в июне 1915 г. и находившийся вместе со своей Рабочей группой, образованной в ноябре того же года, в Петрограде (Литейный, 46). Традиционно историки рассматривали и рассматривают ЦВПК и местные военно-промышленные комитеты (их насчитывалось более 200) как органы мобилизации частной промышленности, игнорируя или преуменьшая их политическое значение [Горбачев 1919; Погребинский 1941, с. 160-200; Сидоров 1973, с.191-212; Юрий 1986; Сергеева 1996; Кюнг 2012; Siegelbaum 1983]. Впервые в историографии политической деятельности руководителей ЦВПК и Рабочей группы, осторожно противореча официальной точке зрения, посвятила несколько страниц своей монографии Б. Б. Граве [Граве 1926]. Политическая деятельность ЦВПК и Рабочей группы, но в качестве побочной, а не самостоятельной темы исследования и с отрицанием революционного характера этой деятельности привлекла внимание В.С.Дякина [Дякин 1967] и В.Я. Лаверычева [Лаверычев 1967]. В позднейшей советской историографии исключением оказался И.П.Лейберов, который, доказывая, согласно официальной точке зрения, что Февральская революция стала итогом деятельности большевиков, тем не менее обратил внимание на участие в ней, хотя и в качестве политических маргиналов (опять-таки - в соответствии с официальным каноном), социалистов и пролетариев, связанных с Рабочей группой и прежде всего с ее низовыми организациями на заводах и фабриках [Лейберов 1979]. Р.А. Кулагин первым особо остановился на политической деятельности ЦВПК, хотя и не связывая ее напрямую с истоками Февральской революции [Кулагин 2001]. Наоборот, А. Б. Николаев отмечает участие ЦВПК в Февральской революции, полагая, однако, что 27 февраля 1917 г. он «играл роль вспомогательной структуры, которая обслуживала интересы центра революции и штаба восстания, действовавших в Государственной думе» [Николаев 2002, c. 239, 245]. Приведенному взгляду мы противопоставили мнение о том, что «Думу, в качестве центра революции, породил ЦВПК» [Куликов 2003, с. 242], и в ряде работ обосновали версию о решающей роли этой организации и ее Рабочей группы при подготовке и проведении Февральской революции [Куликов 2004a, 2004b, с. 134179; 2007a, c. 117-185; 2007b, с. 243-271; Kulikov 2009, p. 8-39; Куликов 2012, с. 69-90; 2014 , с. 165-185, 343-368, 385-406; 2015, с. 121-134]. Наиболее близко к нашей точке зрения подошли О. Р. Айрапетов и Л. Хэймсон, однако первый из них, подразумевая руководителей ЦВПК, писал, что «оппозиция готовилась скорее к перевороту, чем к революции» [Айрапетов 2003, с. 228-229]. Следовательно, налицо приближение к постановке проблемы, нежели к ее решению. Л.Хэймсон указал на радикализм лидеров ЦВПК, которые к началу 1917 г. пришли к выводу о необходимости «безотлагательного принятия революционной тактики» [Хеймсон 2005, с. 189, 190, 191], но так и не уточнил, была ли она все-таки принята, и если да, то к чему это привело. 
Необходимость особого внимания к ЦВПК объясняется прежде всего его личным составом, рекрутировавшимся из представителей общественной контрэлиты, среди которых мы видим будущих вождей Февральской революции. Председателем Бюро ЦВПК с июля 1915 г. стал А. И. Гучков, его заместителем являлся А. И. Коновалов, а товарищами были А. А. Бубликов, М.И. Терещенко и М. М. Федоров. В ЦВПК входили не только предприниматели, но и члены Прогрессивного блока IV Государственной думы и Государственного совета, главноуполномоченный Земского союза и председатель Земгора князь Г. Е. Львов и его секретарь Д. М.Щепкин, главноуполномоченный Городского союза М.В. Челноков [Личный состав военно-промышленных комитетов 1915 , с. 5, 8-28, 85-87]. То же самое наблюдалось и относительно личного состава местных военно-промышленных комитетов. Фактически ЦВПК и подчинявшиеся ему местные комитеты представляли собой политическую организацию антиправительственного толка, поскольку под эгидой А. И. Гучкова объединились не только предприниматели, но и члены Прогрессивного блока в обеих палатах и руководители Земского и Городского союзов и Земгора. Хотя в финансовом отношении военно-промышленные комитеты всецело зависели от казны, которая в 1915-1917 гг., с полного согласия Николая II, выделила им 170 млн руб. [Протопопов 2001, с. 557], большинство лидеров ЦВПК сплачивало неприятие старого порядка. По свидетельству секретаря Рабочей группы меньшевика Б. О.Богданова, в ЦВПК входили «группы буржуазии, настроенные враждебно к царскому режиму» [Богданов 1994, с. 194]. Революционеру вторил его антагонист, начальник Петроградского охранного отделения генерал К.И. Глобачев, который вспоминал, что ЦВПК и местные комитеты «были укомплектованы людьми, стоящими в оппозиции к правительству и трону, начиная от председателя Гучкова и до периферии» [Глобачев 2009, с. 66, 67]. Целью лидеров ЦВПК, и прежде всего его председателя, являлся государственный переворот.

Объективной причиной резкого полевения А. И. Гучкова были поражения русской армии, понесенные ею весной - летом 1915 г. в ходе Первой мировой войны. Выступая 8 марта 1917 г. на торжественном собрании ЦВПК, А. И. Гучков публично признал: «...Два года тесно переплетенной совместной работы с властью и ее органами окончательно убедили нас всех, руководителей нашей организации и всех наших сотрудников, что при наличии современной власти победа для России невозможна, что приходится включить в нашу программу сотрудничества с властью и помощи войне необходимость свержения этой власти, ибо только при этом условии являлись шансы на победу». В результате, подытоживал А.И.Гучков, деятели ЦВПК «вынуждены были включить в основной пункт нашей практической программы переворот, хотя бы и вооруженный» [Отчет о торжественном заседании ЦВПК 1917, с. 17]. Характерно, что А. И. Гучков не делал разницы между переворотом и революцией. 31 июля 1915 г. после беседы с лидером октябристов его софракционер по Петроградской городской думе, прогрессист А.Н. Брянчанинов, передавая мнение своего кумира, заявил французскому послу Ж. М. Палеологу, что Россия «может быть спасена только ценой национальной революции». «Ведь нужно изменить весь государственный строй, - неистовствовал А. Н. Брянчанинов. Наша последняя надежда на спасение - в национальном государственном перевороте» [Палеолог 2003, с. 337-339]. Итак, переворот и революция не трактовались их сторонниками как нечто противоположное. 
В мае 1917 г. А.И.Гучков публично признался, что «стал революционером в 1915 г., придя к твердому убеждению, что самодержавие грозит нам поражением, которое будет иметь катастрофические последствия для страны, и спасти ее можно, только покончив со старым режимом» [Керенский 2005, с. 87]. А. Ф. Керенский подтверждал, что Гучков «стал революционером» в октябре 1915 г., когда не только его однопартийцы, но и большинство кадетов и прогрессистов «от одного слова “революция” приходили в священный ужас» [Керенский 1936, с.460, 461]. Резкое полевение председателя ЦВПК не было секретом и для Департамента полиции, в обобщающем докладе которого за 1915 г. указывалось: «Съездив в Китай, Турцию и Португалию и изучив на месте способы и приемы переворотов в разных странах, а также бывшие у нас бунты во Владивостоке, Севастополе и Кронштадте и дождавшись такого благоприятного времени, как война 1914 г., Гучков начал действовать» [Сенин 1996, с. 92]. Впрочем, А. И. Гучков являлся сторонником революции безотносительно к войне.

Еще при жизни П. А. Столыпина, вспоминал А. И. Гучков, он «изверился в возможности мирной эволюции» [Падение царского режима 1926, с.253]. В январе 1911 г. близкий к лидеру октябристов генерал Е.И. Мартынов лично слышал от него о «необходимости дворцового переворота» [Мартынов 2003, с. 151]. В данном случае сыграла свою роль личная неприязнь А.И.Гучкова к Николаю II, отношения с которым у некогда либерального политика окончательно испортились еще в период III Думы, в начале 1912 г., когда А. И. Гучков с думской трибуны безосновательно обвинил Г.Е.Распутина в хлыстовстве и его политическом влиянии на самодержца. Относя себя к личным врагам Николая II, Гучков, отмечал директор Департамента полиции А. Т. Васильев, говорил в 1915 г.: «Если я не умру раньше, я сам арестую царя» [Васильев 2004, с.454]. К осени 1916 г., воспоминал друг А. И. Гучкова по ЦК «Союза 17 октября» князь А. В. Оболенский, бывший либеральный политик стал «открытым злобным революционером», настроенным «больше всего» против Николая II [Оболенский 2005, с. 364]. Более того, согласно княгине О.В.Палей, близкой к октябристам, свержение монарха вообще перевешивало, с точки зрения А. И. Гучкова, перспективы победы, поскольку однажды он заявил: «Черт с ней, с победой, лишь бы скинуть царя!» [Палей 2005, с. 10]. Так или иначе, но уже в 1915 г. А.И. Гучков был одержим идеями «государственного переворота» и «национальной революции».

Неудивительно, что деятельность ЦВПК имела не только оппозиционный, но и революционный характер. «В глазах правительства, - подчеркивал социал-демократ В.Н. Переверзев, работавший в Московском военно-промышленном комитете, - эти организации Военно-промышленного комитета, вполне понятно, казались крайне опасными. Оно думало, что из этих организаций может развиться революционная зараза, которая охватит всю Россию. Нужно отдать справедливость старому правительству, что оно не ошиблось» [Отчет о торжественном заседании ЦВПК 1917, с. 15]. ЦВПК и местные военно-промышленные комитеты, подчеркивал жандармский генерал П.Г. Курлов, «образовали дополнительное сорганизованное “правительство”, задачей которого было уничтожение существовавшей власти», по причине чего ЦВПК «вылился в чисто революционную организацию» [Курлов 1991, с. 189]. В ЦВПК, писал начальник Дворцовой полиции генерал А. И.Спиридович, «готовилась революция» [Спиридович 2004, с.300]. А по воспоминаниям 
К.И. Глобачева, ЦВПК «был организацией политической и служил исключительно целям подготовки революции» [Глобачев 2009, с.70]. Но революции всегда предшествует заговор, что невольно признал сам А. И. Гучков. Выступая 8 марта 1917 г. на торжественном заседании ЦВПК, его недавний председатель, ставший военным и морским министром, заявил, подразумевая Февральскую революцию: «Господа, этот переворот является не результатом какого-то умного и хитрого заговора, какого-то комплота, работы каких-то замаскированных заговорщиков, которых искали во тьме ночной агенты охранки. Этот переворот явился зрелым плодом, упавшим с дерева. Он явился неизбежным результатом стихийных исторических сил, которые выросли из русской разрыхленной почвы. Это - историческое явление, и в том, что этот переворот является не искусственным творением и не результатом работы какой-то группы заговорщиков, как это было, скажем, в младотурецком или младопортугальском перевороте, кроется, по-моему, гарантия ее незыблемой прочности» [Отчет о торжественном заседании ЦВПК 1917, с. 18].

Под «младотурецким» и «младопортугальским» переворотами А.И.Гучков имел в виду Турецкую и Португальскую революции 1908 и 1910 гг., первая из которых закончилась установлением конституционной монархии, а вторая - заменой монархии республикой. Но разве не абсурдно с точки зрения обыкновенного здравого смысла, не говоря уже о так называемом научном сознании, звучит утверждение о том, что и в Европе (Португалия), и в Азии (Турция) революции являются «искусственным творением» и «результатом работы какой-то группы заговорщиков», и только в России революция - порождение одной стихии?! Так, сам того не желая, А. И. Гучков раскрыл карты и выдал тайну своего заговора.

«Возникновение тайных организаций с целями переворота, - сообщил А. Ф. Керенский Б.И. Николаевскому, - относится к зиме 1915-1916 гг.». А.Ф.Керенский выделял две «основные группировки»: «вокруг военно-промышленных комитетов и вокруг Земгора». Во главе первой группировки стояли А.И.Гучков, А.И.Коновалов, М.И.Терещенко, во главе второй - Г.Е.Львов, В.В.Вырубов, С.М.Леонтьев, Д.М.Щепкин [Платонов 2000, с.269, 270]. Поскольку Г.Е.Львов, председатель Земгора, и его секретарь Д. М. Щепкин одновременно были членами ЦВПК, можно утверждать, что обе «группировки» являлись ответвлениями единого заговора, свившего себе гнездо в ЦВПК. По сути дела, уже в конце 1915 г. ЦВПК в лице своих руководителей превратился в штаб общественной контрэлиты по организации революции. Доказательством того, что осенью 1915 г. А. И. Гучков и его соратники действительно стали революционерами, по крайней мере - тайными, нельзя не признать их явное отношение к созданию Рабочей группы ЦВПК.Необходимость политической мобилизации пролетариата для обеспечения массового, «стихийного», характера революции и тем самым облегчения ее легитимации для руководителей ЦВПК была более чем очевидной. На состоявшемся 20 ноября 1915 г. у А.И. Коновалова совещании общественных деятелей он солидаризировался с присутствовавшим на совещании А. Ф. Керенским, который высказался за то, чтобы «продемонстрировать народное недовольство против действий правительства какими-либо забастовками или иными демонстративными эксцессами». А. И. Коновалов заявил, что «народную массу пора поднимать», дабы «обуздать наглую власть» [Граве 1926, с. 305, 306]. Позднее, в марте 1916 г., Московское охранное отделение сообщало, что А.И. Коновалов является сторонником уличных вы- 
ступлений пролетариата, желая «ущемить хвост правительству и поднести кулак к его носу», и готов «оплатить расходы по созданию Совета рабочих депутатов» под флагом ЦВПК [Тютюкин 1972, с.297]. Инструментом политической мобилизации пролетариата и стала Рабочая группа, аналог Совета рабочих депутатов.

Секретарь Общего собрания ЦВПК и бывший народоволец М. В. Новорусский объяснял введение представителей рабочих в «организацию, враждебную им по классовым интересам», осознанием буржуазными лидерами «необходимости объединения всех общественных элементов на борьбу одновременно на два фронта: с врагом внешним и врагом внутренним, т. е. со старым режимом». Более того, согласно свидетельству Новорусского, руководители ЦВПК, «в большинстве представители капиталистических групп, легально и гласно допустили в свою среду инородную группу» именно для «подготовки революции», а потому Департамент полиции полагал «не без основания», что ЦВПК «подрывает основы и корни» [Новорусский 1922, с.27-29]. Подразумевая Рабочую группу, А. Т. Васильев отмечал, что «под видом патриотической организации, содействующей победе российской армии, Гучков организовал боевую революционную группу, призванную стать средством реализации его предательских замыслов» [Васильев 2004, с. 468]. Показательно в этом смысле то, что происходило 29 ноября 1915 г. в главном зале ЦВПК, на Литейном, 46, на собрании 153 выборщиков, избранных на заводах и фабриках Петрограда, - они, в свою очередь, и избрали Рабочую группу.

А.И. Гучков открыл собрание выборщиков Рабочей группы речью, в которой иносказательно намекнул на необходимость революции, подчеркнув, что «мы все должны победить врага и вместе с тем стремиться к самому лучшему устройству внутренней жизни России». То, что руководитель ЦВПК имел в виду именно революцию, открыто подтвердил председатель собрания меньшевик К.А. Гвоздев, выступивший за организацию «общественных сил России для борьбы с нападающей Германией и для борьбы с нашим страшным внутренним врагом - самодержавным строем», отмечая, что для достижения этих двух целей и «необходимо деятельное участие в работах военно-промышленных комитетов». Говоря о том, о чем А.И.Гучков умалчивал, К.А.Гвоздев заявил, что «власть должна перейти из рук правительства в руки буржуазии» и Россия - «накануне буржуазной революции». «Уже созрели, - заключил К.А. Гвоздев, - все предпосылки для перемены существующего политического строя» [Шляпников 1992a, с. 122, 134]. Таким образом, лозунг «Революция ради обороны страны» объединил представителей общественной и революционной контрэлит, буржуазии и пролетариата, несмотря на разделявшие их социальные противоречия.

Центр тяжести оборонческой позиции находился именно в исповедании необходимости революции: Рабочая группа, подчеркивал ее секретарь Е. Маевский, видела в «организации самозащиты» путь, который «вернее всего должен был привести Россию к революционному перевороту» [Маевский 1918, с.4-5]. В Рабочую группу ЦВПК оказались избранными 10 человек, в Рабочую группу Петроградского областного военно-промышленного комитета - 6, причем из 16 человек 13 числились меньшевиками-оборонцами, 3 - эсерами. Во главе Рабочей группы ЦВПК стояло выборное Бюро в составе шести человек - его председателем, как и председателем группы в целом, являлся К. А. Гвоздев. У Рабочей группы было 8 секретарей, в том числе один главный (меньшевик Б.О.Богданов, «подлинный мотор» 
Рабочей группы [Денике 1994, с.221]) и два старших (меньшевики Е. Маевский (В. А. Гутовский) и Л. М. Пумпянский). По свидетельству А. И. Коновалова, выборы в обе группы охватили 101 предприятие столицы с общим количеством рабочих в 219 тыс. человек [Государственная дума 1995, с. 290]. Учитывая, что общее количество петроградских пролетариев насчитывало к указанному сроку около 300 тыс. человек [Лейберов 1979, с. 13], очевидно, что через Рабочую группу и 153 выборщика ЦВПК опирался на достаточно широкие слои столичного пролетариата.

Первая же резолюция Рабочей группы ЦВПК, принятая 29 ноября 1915 г., имела, по свидетельству Б. О. Богданова, «антицаристскую направленность» [Богданов 1994, с. 195], т. е. революционный характер, ибо в ней говорилось о «коренной ломке режима», причем очередной задачей пролетариата резолюция объявляла «борьбу за созыв Учредительного собрания» с тем, чтобы «вырвать власть из рук ее нынешних носителей» [Рабочее движение в годы войны 1925, с.277]. Характерно, что заседание Рабочей группы проходило под защитой А. И. Гучкова, который, вспоминал Б.О.Богданов, лично «охранял» членов группы, ожидая вмешательства полиции и демонстративно подчеркивая «полную самостоятельность и независимость рабочего представительства» [Богданов 1994, с. 195]. После того как К. А.Гвоздев озвучил резолюцию, А. И. Гучков заметил А.И. Коновалову: «Какие молодцы наши рабочие» [Хеймсон 2005, с.189]. К К.А. Гвоздеву, который, вспоминал большевик А. Г.Шляпников, был «частым гостем» гучковского кабинета [Шляпников 1992а, с. 119], А. И. Гучков, по его признанию, относился «с большими симпатиями и доверием» [Падение царского режима 1926, с. 286]. А. И. Коновалов же, отмечал тот же А. Г. Шляпников, получил известность как «душа военно-промышленных социалистов» [Шляпников 1992b, с. 37]. А. И. Гучков и А. И. Коновалов, писал А. И. Спиридович, «покровительствовали» К. А. Гвоздеву и «содействовали деятельности рабочих групп» [Спиридович 2004, с.300-301]. На состоявшемся 3 декабря 1915 г. Общем собрании ЦВПК революционная резолюция Рабочей группы не вызвала никаких возражений со стороны его руководителей [Меньшевики 1996, с. 406, 408-409]. Все это лишний раз доказывало, что цель Рабочей группы - революция - была и целью ЦВПК: то, о чем умалчивали гучковцы, говорили гвоздевцы.

Мобилизацию пролетариата обеспечивали заседания Рабочей группы, собиравшие в здании ЦВПК до 500 человек [Рафес 1922, с. 179] (среди них были деятели больничных касс и профсоюзов, меньшевики, эсеры, бундовцы и большевики, члены Фракций меньшевиков и трудовиков IV Государственной думы и их лидеры Н.С. Чхеидзе и А.Ф. Керенский, посетители политического кружка социал-демократа Н.Д. Соколова [Арский 1923, с. 87]), 10 постоянных комиссий, созданных при группе [К истории гвоздевщины 1934, с.41, 57-59, 81], наконец, полностью контролировавшиеся гвоздевцами рабочие кооперативы, которые в июле 1916 г. объединил Петроградский союз потребительных обществ [Государственная дума 1995, c. 293]. В 1915-1917 гг. Рабочая группа ЦВПК фактически становится Советом рабочих депутатов, единственным легальным центром рабочего движения в масштабах не только Петрограда, но и всей России.

Официальная деятельность Рабочей группы по улучшению бытовых условий жизни пролетариата скрывала неофициальную, связанную с подготовкой революции, по причине чего делопроизводство группы имело «двойное дно»: наряду с абсолютно безобидными бумагами через него проходили откровенно антипра- 
вительственные документы. «Двойное дно» обеспечивало невозможность утечки информации, компрометирующей Рабочую группу в глазах властей: Б. О. Богданов, «хранитель всех ее документов», приносил в кабинет М.В.Новорусского «те документы, которые надо было сохранить от постороннего глаза и, в особенности, сохранить на случай обыска». Однако уже после падения монархии эта наиболее интересная часть архива группы пропала и до сих пор не найдена. Тем не менее, опираясь на информацию из пропавших документов, М. В. Новорусский подтверждал, что «подготовка революции, действительно, велась Рабочей группой» [Новорусский 1922, с.27-28]. Рабочие группы, вспоминал меньшевик П.А. Гарви, были «единственными связанными с рабочей массой организующими центрами надвигающейся революции» [Гарви 1989, с. 12-13]. Революцию, подчеркивал А. И.Спиридович, «готовила Рабочая фракция комитета под председательством Гвоздева» [Спиридович 2004, с. 300]. Рабочая группа, по сведениям П. Г. Курлова, «посвящала все время почти исключительно обсуждению планов революционных партий, направленных к свержению существовавшего государственного строя» [Курлов 1991, с. 189-190]. Жандармский генерал П.П.Заварзин писал, что К.А. Гвоздев и его соратники «создали на заводах революционные ячейки и постепенно приобрели значение руководителей массами» как в столице, так и в провинции - через своих делегатов, в результате чего ЦВПК стал «прикрытием подпольных организаций, члены коих, под видом осведомления масс о ходе работ, разъезжали по местам, организовывали и настраивали рабочих, связывая ячейки с подпольными центрами по восходящей линии, откуда они далее и получали указания» [Заварзин 2004, с. 111].

\section{Источники и литература}

Айрапетов О.Р. Генералы, либералы и предприниматели: работа на фронт и на революцию (19071917). М.: Три квадрата, 2003. 253 с.

Арский Р. В Петрограде во время войны (Из воспоминаний) // Красная летопись (Ленинград). 1923. № 7. C. 75-90.

Богданов Б. О. Фрагменты воспоминаний // Богданова Н. Б. Мой отец - меньшевик. СПб.: Мемориал, 1994. С. 190-205.

Брачев В. С. «Победоносный февраль» 1917 года: масонский след // Масоны и Февральская революция 1917 года. М.: Яуза-Пресс, 2007. С. 7-236.

Бурджалов Э. Н. Вторая русская революция. Восстание в Петрограде. М.: Наука, 1967. 408 с.

Бъёркегрен Х. Скандинавский транзит. Российские революционеры в Скандинавии. 1906-1917. М.: Омега, 2007. 544 c.

Васильев А. Т. Охрана: русская секретная полиция // «Охранка». Воспоминания руководителей охранных отделений: в 2 т. М.: НЛО, 2004. Т. 2. С. 345-515.

Гарви П. А. Профсоюзы и кооперация после революции. Нью-Йорк: Chalidze Publicaition, 1989. 208 c.

Глобачев К. И. Правда о русской революции. Воспоминания быв. начальника Петроградского охранного отделения. М.: РОССПЭН, 2009. 519 с.

Горбачев И. Л. Хозяйство и финансы военно-промышленных комитетов. М.: [Б. и.], 1919. 40 с.

Государственная дума. 1906-1917. Стенографические отчеты: в 4 т. М.: Правовая культура, 1995. Т. 4. $368 \mathrm{c}$.

Граве Б. Б. К истории классовой борьбы в России в годы империалистической войны. Июль $1914-$ февраль 1917 г. Пролетариат и буржуазия. М.; Л.: Государственное издательство, 1926. 414 с.

Денике Ю. П. Б. О. Богданов в начале 1918 г. // Богданова Н. Б. Мой отец - меньшевик. СПб.: Мемориал, 1994. С. 221-223.

Дякин В. С. Русская буржуазия и царизм в годы Первой мировой войны (1914-1917). Л.: Наука, 1967. $374 \mathrm{c}$.

Заварзин П. П. Жандармы и революционеры // «Охранка». Воспоминания руководителей охранных отделений: в 2 т. М.: НЛО, 2004. Т. 2. С.7-138. 
Зарин А. Е. Первая годовщина Великой русской революции. Пг.: [Б. и.], 1918. 31 с.

Земан 3., Шарлау У. Кредит на революцию. План Парвуса. М.: Центрполиграф, 2007. 319 с.

К истории гвоздевщины. «Бюллетени» Рабочей группы ЦВПК // Красный архив (Москва). 1934. T.67. C. $28-92$.

Катков Г. М. Февральская революция. М.: Русский путь, 1997. 432 с.

Керенский А. Ф. А.И. Гучков. Из воспоминаний // Современные записки (Париж). 1936. Т. 60. С. $460-$ 463.

Керенский А. Ф. Русская революция. 1917. М.: Центрполиграф, 2005. 384 с.

Кобылин В. С. Анатомия измены. Император Николай II и генерал-адъютант М. В. Алексеев. СПб.: Царское дело, 1998. 494 с.

Кулагин Р.А. Политическая деятельность Центрального военно-промышленного комитета, 19151918 гг.: автореф. дис. ... канд. ист. наук. СПб., 2001. 217 с.

Куликов С.В.Бюрократическая элита Российской империи накануне падения старого порядка (1914-1917). Рязань: НРИИД, 2004а. 472 с.

Куликов С. В. Глава III. Совет министров и падение монархии // Первая мировая война и конец Российской империи: в 3 т. Т. 3. Февральская революция. СПб.: Лики России, 2014. С. 165-185.

Куликов С. В. Глава V. Ставка: 23 февраля - 1 марта // Первая мировая война и конец Российской империи: в 3 т. Т. 3: Февральская революция. СПб.: Лики России, 2014. С. 343-368.

Куликов С. В. Глава VII. Февральская революция. СПб.: Лики России, 2014. С. 385-406.

Куликов С.В.Прогрессивный блок и левые фракции IV Государственной думы и Рабочая группа Центрального военно-промышленного комитета (1915-1917 гг.) // Первая мировая война и Государственная дума. Материалы научной конференции. Казань, 17-18 октября 2014 г. М.: Издво Государственной думы, 2015. С. 121-134.

Куликов С. В. «Революции неизменно идут сверху...». Падение царизма сквозь призму элитистской парадигмы // Нестор. 2007а. № 11: Смена парадигм: современная русистика. Источники, исследования, историография. С. 117-185.

Куликов С. В. Рецензия на кн.: Николаев А. Б. Государственная дума в Февральской революции: очерки истории. Рязань, 2002 // Клио (С.-Петербург). 2003. № 1 (20). С. 240-244.

Куликов С. В. Февральская «революция сверху» или фиаско «генералов для пронунсиаменто» // Россия XXI (Москва). 2004b. № 4. С. 134-179.

Куликов С. В. Центральный военно-промышленный комитет и Февральская революция 1917 г. К вопросу о соотношении факторов организованности и стихийности // Власть, общество и реформы в России: история, источники, историография. СПб.: Олеариус Пресс, 2007b. С. 243-271.

Куликов С. В. Центральный военно-промышленный комитет накануне и в ходе Февральской революции 1917 г. // Российская история. 2012. № 1. С. 69-90.

Курлов П. Г. Гибель Императорской России. М.: Современник, 1991. 255 с.

Кюнг П. А. Мобилизация экономики и частный бизнес в России в годы Первой мировой войны. М.: РГГУ, 2012. $240 \mathrm{c.}$

Лаверычев В.Я. По ту сторону баррикад (Из истории борьбы московской буржуазии с революцией). М.: Мысль, 1967. 288 с.

Лейберов И. П.На штурм самодержавия. М.: Мысль, 1979. 311 с.

Личный состав военно-промышленных комитетов. По 24 октября 1915 г. Пг.: ЦВПК, 1915. 196 с.

Люттввак Э. Н. Государственный переворот: практическое пособие. М.: Университет Дмитрия Пожарского, 2012. 326 с.

Маевский Е. Канун революции. Из истории рабочего движения накануне революции 1917 г. Деятельность рабочего представительства при ЦВПК (по материалам). Пг.: [Б. и.], 1918. 120 с.

Мартынов Е. И. Царская армия в Февральском перевороте // Мартынов Е. И. Политика и стратегия. М.: Финансовый контроль, 2003. С. 121-272.

Мельгунов С.П.На путях к дворцовому перевороту. Заговоры перед революцией 1917 года. М.: Бородино-Е, 2003. 256 c.

Меньшевики. Документы и материалы. 1903-1917 гг. М.: РОССПЭН, 1996. 408 с.

Милюков П.Н. История второй русской революции. М.: РОССПЭН, 2001. 767 с.

Мини И. И. История Великого Октября: в 3 т. Т. 1. Свержение самодержавия. М.: Наука, 1977. 784 с.

Миронов Б. Н. Благосостояние населения и революции в имперской России: XVIII - начало XX века. М.: Новый хронограф, 2010. 911 с.

Мультатули П. В. Император Николай II и заговор 17-го года. М.: Вече, 2013. 432 с.

Николаев А. Б. Государственная дума в Февральской революции: очерки истории. Рязань: НРИИД, 2002. $302 \mathrm{c}$. 
Николаев А.Б. 27 февраля 1917 г.: к вопросу о центрах революции // Петербургская историческая школа. Альманах. Памяти В. И. Старцева. СПб.: Клио, 2002. С. 235-251.

Николаев А.Б. Революция и власть. IV Государственная дума 27 февраля - 3 марта 1917 г. СПб.: РГПУ им. А. И. Герцена, 2005. 695 с.

Никонов В. А. Крушение России. 1917. М.: АСТ, 2016. 698 с.

Новорусский М. В. Рабочая группа Военно-промышленного комитета // Историко-революционный бюллетень (Петроград). 1922. № 2-3. С.27-30.

Оболенский А. В. Мои воспоминания // Проблемы истории Русского зарубежья: материалы и исследования. Вып. 2. М.: Наука, 2005. С. 314-375.

Отчет о торжественном заседании ЦВПК 8 марта 1917 г. в Александровском зале Петроградской городской думы. Пг.: ЦВПК, 1917. 24 с.

Падение царского режима. Стенографические отчеты допросов и показаний, данных в 1917 г. в ЧСК Временного правительства: в 7 т. Т.6. М.; Л.: Государственное издательство, 1926. 416 с.

Палей О. В. Воспоминания. М.: Захаров, 2005. 240 с.

Палеолог Ж. М. Дневник посла. М.: Захаров, 2003. 830 с.

Платонов О. А. Тайная история масонства. Документы и материалы: в 2 т. М.: Русский вестник, 2000. T.2. $736 \mathrm{c}$.

Погребинский А. П. Военно-промышленные комитеты // Исторические записки. 1941. Т. 11. С.160200.

Протопопов А. Д. Предсмертная записка // Искендеров А. А.Закат империи. М.: Вопросы истории, 2001. С. $552-572$.

Рабочее движение в годы войны. М.: Вопросы труда, 1925. 364 с.

Рабес М. Г. Мои воспоминания // Былое (Петроград). 1922. № 19. С. 177-197.

Сафонов М. М. Ложь и правда об отречении Николая II // Нестор. 2005. № 3: Между двух революций. 1905-1917. Источники, исследования, историография. С. 215-272.

Сенин А. С. А. И. Гучков. М.: Скрипторий, 1996. 268 с.

Сергеева С. Л. Военно-промышленные комитеты в годы Первой мировой войны. М.: МАДИ (ТУ), 1996. $141 \mathrm{c}$.

Сидоров А.Л.Экономическое положение России в годы Первой мировой войны. М.: Наука, 1973. $654 \mathrm{c}$.

Спиридович А. И. Великая война и Февральская революция. Воспоминания. Минск: Харвест, 2004. $720 \mathrm{c}$.

Стариев В. И. Тайны русских масонов. СПб.: ДАРК, 2004. 320 с.

Трауптман Й., Шиссер Г. Русская рулетка. Немецкие деньги для русской революции. М.: Астрель, 2004. 254 c.

Тютюкин С.В. Война, мир, революция. Идейная борьба в рабочем движении России 1914-1917 гг. М.: Мысль, 1972. 304 с.

Хасегава Ц. Февральская революция // Критический словарь русской революции: 1914-1921. СПб.: Нестор-История, 2014. С. 60-70.

Хеймсон Л.Проблема политической и социальной стабильности в городской России накануне войны и революции: современный взгляд // Нестор. 2005. № 3. Между двух революций. 19051917. Источники, исследования, историография. С. 162-192.

Хереш Э. Купленная революция. Тайное дело Парвуса. М.: ОЛМА-ПРЕСС; Образование, 2004. 380 с.

Шляпников А. Г. Канун семнадцатого года. Семнадцатый год: в 3 т. Т. 1. М.: Политиздат, 1992а. 383 с.

Шляпников А. Г. Канун семнадцатого года. Семнадцатый год: в 3 т. Т. 2. М.: Республика, 1992b. 496 c.

Юрий М. Ф. Центральный военно-промышленный комитет. 1915-1917 гг. Организационное устройство и деятельность. Черновцы: [Б. и.], 1986. 224 с.

Якобий И. П. Император Николай II и революция // Император Николай II и революция. СПб.: Общество святителя Василия Великого, 2005. С. 37-368.

Яковлев Н.Н. 1 августа 1914. М.: Москвитянин, 1993. 320 с.

Hasegawa T. The February Revolution. Petrograd, 1917. Seattle; London: University of Washington Press, $1981.652 \mathrm{p}$.

Kulikov S. «Revolutions Invariably Come from Above». The Fall of Tsarism Through the Prism of the Elite Circulation Paradigm // Russian Studies in History. 2009. Spring. Vol. 47, N 4. P. 8-39.

Melancon M. Rethinking Russia's February Revolution: Anonymous Spontaneity or Socialist Agency? Pittsburgh: The Center for Russian and East European Studies, 2000. 44 p.

Siegelbaum L. The politics of industrial mobilization in Russia, 1914-1917: A study of the war-industries committees. London: Macmillan in association with St. Antony's College (Oxford), 1983. 312 p. 


\section{References}

Airapetov O. R. Generaly, liberaly i predprinimateli: rabota na front i na revolyuciyu (1907-1917). Moscow, Tri kvadrata Publ., 2003, 253 p. (In Russian)

Arsky R.V Petrograde vo vremya vojny (Iz vospominanij). Krasnaya letopis' [Red chronicle] (Leningrad), 1923, no. 7, pp. 75-90. (In Russian)

Bogdanov B. O. Fragmenty vospominanij]. Bogdanova N.B.Moj otec - men'shevik. St. Petersburg, Memorial Publ., 1994, pp. 190-205. (In Russian)

Brachev V.S. "Pobedonosnyj fevral'” 1917 goda: masonskij sled. Masony i Fevral'skaya revolyuciya 1917 goda. Moscow, Yauza-Press Publ., 2007, p.7-236. (In Russian)

Burdzhalov E. N. Vtoraya russkaya revolyuciya. Vosstanie v Petrograde. Moscow, Nauka Publ., 1967, 408 p. (In Russian)

Bjorkegren H.Skandinavskij tranzit. Rossijskie revolyucionery v Skandinavii. 1906-1917. Moscow, Omega Publ., 2007, 544 p. (In Russian)

Vasil'iev A.T. Ohrana: russkaya sekretnaya policiya. Vospominaniya rukovoditelej ohrannyh otdelenij. In 2 vols. Moscow, NLO Publ., 2004, volume 2, pp. 345-515. (In Russian)

Garvi P.A.Profsoyuzy i kooperaciya posle revolyucii. New York: Chalidze Publicaition, 1989, 208 p. (In Russian)

Globachev K. I. Pravda o russkoj revolyucii. Vospominaniya byvshego nachal'nika Petrogradskogo ohrannogo otdeleniya. Moscow, ROSSPEN Publ., 2009, 519 p. (In Russian)

Gorbachev I.L.Hozyajstvo i finansy voenno-promyshlennyh komitetov. Moscow, [S.n.], 1919, 40 p. (In Russian)

Gosudarstvennaya duma. 1906-1917. Stenograficheskie otchety. In 4 vols. Moscow, Pravovaya kul'tura Publ., 1995, volume 4, 368 p. (In Russian)

Grave B. B. K istorii klassovoj bor'by v Rossii v gody imperialisticheskoj vojny. Iyul' 1914 - fevral' $1917 \mathrm{~g}$. Proletariat i burzhuaziya. Moscow; Leningrad, Gosudarstvennoe izdatel'stvo, 1926, 414 p. (In Russian)

Denike Y.P. B. O. Bogdanov v nachale 1918 g. Bogdanova N. B. Mojotec-men'shevik t. Petersburg, Memorial Publ., 1994, pp. 221-223. (In Russian)

Dyakin V.S.Russkaya burzhuaziya i carizm v gody Pervoj mirovoj vojny (1914-1917). Leningrad, Nauka Publ., 1967, 374 p. (In Russian)

Zavarzin P.P.Zhandarmy i revolyucionery. "Ohranka». Vospominaniya rukovoditelej ohrannyh otdelenij. In 2 vols. Moscow, NLO Publ., 2004, volume 2, pp. 7-138. (In Russian)

Zarin A.E. Pervaya godovshchina Velikoj russkoj revolyucii. Petrograd, [s. n.], 1918, 31 p. (In Russian)

Zeman Z., Sharlow W. Kredit na revolyuciyu. Plan Parvusa. Moscow, Centrpoligraf Publ., 2007, 319 p. (In Russian)

K istorii gvozdevshchiny. "Byulleteni” Rabochej gruppy CVPK. Krasnyj arhiv [Red archive] (Moscow), 1934, volume 67, pp. 28-92. (In Russian)

Katkov G. M. Fevral'skaya revolyuciya. Moscow, Russkij put' Publ., 1997, 432 p. (In Russian)

Kerensky A. F. A. I. Guchkov. Iz vospominanij. Sovremennye zapiski [Modern notes] (Paris), 1936, volume 60, pp. 460-463. (In Russian)

Kerensky A. F. Russkaya revolyuciya. 1917. Moscow, Centrpoligraf Publ., 2005, 384 p. (In Russian)

Kobylin V.S. Anatomiya izmeny. Imperator Nikolaj II i general-ad'yutant M. V.Alekseev. St. Petersburg, Tzarskoe delo Publ., 1998, 494 p. (In Russian)

Kulagin R.A.Politicheskaya deyatel'nost' Central'nogo voenno-promyshlennogo komiteta, 1915-1918 gg. Abstract of Cand. Diss. St. Petersburg, 2001, 217 p. (In Russian)

Kulikov S. V. Byurokraticheskaya ehlita Rossijskoj imperii nakanune padeniya starogo poryadka (1914-1917). Ryazan', NRIID Publ., 2004a, 472 p. (In Russian)

Kulikov S. V. Glava III. Sovet ministrov i padenie monarhii. Pervaya mirovaya vojna i konec Rossijskoj imperii. Volume 3. Fevral'skaya revolyuciya. St. Petersburg, Liki Rossii Publ., 2014, pp. 165-185. (In Russian)

Kulikov S. V.Glava V.Stavka: 23 fevralya - 1 marta. Pervaya mirovaya vojna i konec Rossijskoj imperii. Volume 3. Fevral'skaya revolyuciya. St. Petersburg, Liki Rossii Publ., 2014, pp. 343-368. (In Russian)

Kulikov S. V. Glava VII. Otrechenie Nikolaya II. Pervaya mirovaya vojna i konec Rossijskoj imperii. Volume 3. Fevral'skaya revolyuciya. St. Petersburg, Liki Rossii Publ., 2014, pp. 385-406. (In Russian)

Kulikov S. V. Progressivnyj blok i levye frakcii IV Gosudarstvennoj dumy i Rabochaya gruppa Central'nogo voenno-promyshlennogo komiteta (1915-1917 gg.). Pervaya mirovaya vojna $i$ Gosudarstvennaya duma. Materialy nauchnoj konferencii. Kazan', 17-18 oktyabrya 2014 g. Moscow, Izdatel'stvo Gosudarstvennoj dumy, 2015, pp. 121-134. (In Russian) 
Kulikov S. V. “Revolyucii neizmenno idut sverhu...”. Padenie carizma skvoz' prizmu ehlitistskoj paradigmy. Nestor (St.-Petersburg), 2007a, no. 11. Smena paradigm: sovremennaya rusistika. Istochniki, issledovaniya, istoriografiya, pp. 117-185. (In Russian)

Kulikov S. V. Recenziya na knigu: Nikolaev A. B. Gosudarstvennaya duma v Fevral'skoj revolyucii: ocherki istorii. Ryazan', 2002 [Book Review]. Klio, 2003, no. 1 (20), pp. 240-244. (In Russian)

Kulikov S. V.Central'nyj voenno-promyshlennyj komitet i Fevral'skaya revolyuciya 1917 g. K voprosu o sootnoshenii faktorov organizovannosti i stihijnosti. Vlast', obshchestvo i reformy $v$ Rossii: istoriya, istochniki, istoriografiya. St. Petersburg, Olearius Press, 2007b, pp. 243-271. (In Russian)

Kulikov S. V.Central'nyj voenno-promyshlennyj komitet nakanune i v hode Fevral'skoj revolyucii $1917 \mathrm{~g}$. Rossijskaya istoriya, 2012, no. 1, pp. 69-90. (In Russian)

Kulikov S.V. Fevral'skaya "revolyuciya sverhu" ili fiasko "generalov dlya pronunsiamento". Rossiya XXI. Moscow, 2004b, no. 4, pp. 134-179. (In Russian)

Kurlov P. G. Gibel' Imperatorskoj Rossii. Moscow, Sovremennik Publ., 1991, 255 p. (In Russian)

Kyung P. A. Mobilizaciya ehkonomiki i chastnyj biznes v Rossii v gody Pervoj mirovoj vojny. Moscow, RGGU Publ., 2012, 240 p. (In Russian)

Laverychev V. Y. Po tu storonu barrikad (Iz istorii bor'by moskovskoj burzhuazii s revolyuciej). Moscow, Mysl' Publ., 1967, 288 p. (In Russian)

Leyberov I. P. Na shturm samoderzhaviya. Moscow, Mysl' Publ., 1979, 311 p. (In Russian)

Lichnyj sostav voenno-promyshlennyh komitetov. Po 24 oktyabrya 1915 g. rograd, CVPK Publ., 1915, 196 p. (In Russian)

Luttwak E. N. Gosudarstvennyj perevorot. Prakticheskoe posobie. Moscow, Dmitry Pozharsky University Press, 2012, 326 p. (In Russian)

Mayewski E. Kanun revolyucii. Iz istorii rabochego dvizheniya nakanune revolyucii $1917 \mathrm{~g}$. Deyatel'nost' rabochego predstavitel'stva pri CVPK (po materialam). Petrograd, [S. n.], 1918, 120 p.

Martynov S.P.Carckaya armiya v Fevral' skom perevorote. Martynov E.I.Politika i strategiya. Moscow, Finansovyj kontrol' Publ., 2003, p. 121-272. (In Russian)

Mel'gunov S.P.Na putyah $k$ dvorcovomu perevorotu. Zagovory pered revolyuciej 1917 goda. Moscow, Borodino-E Publ., 2003, 256 p. (In Russian)

Men'sheviki. Dokumenty i materialy. 1903-1917 gg. Moscow, ROSSPEN Publ., 1996, 408 p. (In Russian)

Milyukov P. N. Istoriya vtoroj russkoj revolyucii. Moscow, ROSSPEN Publ., 2001, 767 p. (In Russian)

Mintz I. I. Istoriya Velikogo Oktyabrya. In 3 vols. Volume 3. Sverzhenie samoderzhaviya. Moscow, Nauka Publ., 1979, 784 p. (In Russian)

Mironov B. N. Blagosostoyanie naseleniya i revolyucii v imperskoj Rossii: XVIII - nachalo HKH veka .Moscow, Novyj hronograf Publ., 2010, 911 p. (In Russian)

Mul'tatuli P. V. Imperator Nikolaj II i zagovor 17-go goda Moscow, Veche Publ., 2013, 432 p. (In Russian)

Nikolaev A. B. Gosudarstvennaya duma v Fevral'skoj revolyucii: ocherki istorii. Ryazan', NRIID Publ., 2002. 302 p. (In Russian)

Nikolaev A.B. 27 fevralya 1917 g.: k voprosu o centrah revolyucii. Peterburgskaya istoricheskaya shkola. Al'manah. Pamyati V. I. Starceva. St. Petersburg, Klio Publ., 2002, pp. 235-251. (In Russian)

Nikolaev A. B. Revolyuciya i vlast': IV Gosudarstvennaya duma 27 fevralya - 3 marta $1917 \mathrm{~g}$. St. Petersburg, Russian State Pedagogical University named by A. I. Gertsen Press, 2005, 695 p. (In Russian)

Nikonov V. A. Krushenie Rossii. 1917. Moscow, AST Publ., 2016, 698 p. (In Russian)

Novorussky M. V. Rabochaya gruppa Voenno-promyshlennogo komiteta. Istoriko-revolyucionnyj byulleten' [Historical-revolutionary bulletin] (Petrograd), 1922, no. 2-3, pp. 27-30. (In Russian)

Obolensky A. V.Moi vospominaniya. Problemy istorii Russkogo zarubezhya: materialy i issledovaniya]. Volume 2. Moscow, Nauka Publ., 2005, pp. 314-375. (In Russian)

Otchet o torzhestvennom zasedanii CVPK 8 marta 1917 g. $v$ Aleksandrovskom zale Petrogradskoj gorodskoj dumy. Petrograd, CVPK Publ., 1917, 24 p. (In Russian)

Padenie carskogo rezhima. Stenograficheskie otchety doprosov i pokazanij, dannyh $v 1917 \mathrm{~g} . \quad \mathrm{C}$ CHSK Vremennogo pravitel'stva. In 7 vols. Volume 6. Moscow; Leningrad, Gosudarstvennoe izdatel'stvo, 1926, 416 p. (In Russian)

Paley O. V. Vospominaniya. Moscow, Zakharov Publ., 2005, 240 p. (In Russian)

Paleolog J. M. Dnevnik posla. Moscow, Zakharov Publ., 2003, 830 p. (In Russian)

Platonov O. A. Tajnaya istoriya masonstva. Dokumenty i materialy. In 2 vols. Volume 2. Moscow, Russkij vestnik Publ., 2000, 736 p. (In Russian)

Pogrebinsky A. P. Voenno-promyshlennye komitety. Istoricheskie Zapiski, 1941, volume 11, pp. 160-200. (In Russian) 
Protopopov A.D.Predsmertnaya zapiska. Iskenderov A. A.Zakat Imperii. Moscow, Voprosy istorii Publ., 2001, pp. 552-572. (In Russian)

Rabochee dvizhenie v gody vojny. Moscow, Voprosy truda Publ., 1925, 364 p. (In Russian)

Rafes M. G. Moi vospominaniya. Byloe [Past] (Petrograd), 1922, no. 19, pp. 177-197. (In Russian)

Safonov M. M.Lozh' i pravda ob otrechenii Nikolaya II. Nestor, 2005, no. 3. Mezhdu dvuh revolyucij. 19051917. Istochniki, issledovaniya, istoriografiya, pp. 215-272. (In Russian)

Senin A.S.A.I. Guchkov. Moscow, Scriptorium Publ., 1996, 268 p. (In Russian)

Sergeeva S.L. Voenno-promyshlennye komitety v gody Pervoj mirovoj vojny. Moscow, MADI (TU) Publ., 1996, 141 p. (In Russian)

Sidorov A.L.Ehkonomicheskoe polozhenie Rossii v gody Pervoj mirovoj vojny. Moscow: Nauka Publ., 1973, 654 p. (In Russian)

Spiridovich A. I. Velikaya vojna i Fevral'skaya revolyuciya. Vospominaniya. Minsk, Harvest Publ., 2004, 720 p. (In Russian)

Startsev V.I. Tajny russkih masonov. St. Petersburg, DARK Publ., 2004, 320 p. (In Russian)

Trauptmann J., Shisser G. Russkaya ruletka. Nemeckie den'gi dlya russkoj revolyucii. Moscow, Astrel' Publ., 2004, 254 p. (In Russian)

Tutukin S. V. Vojna, mir, revolyuciya. Idejnaya bor'ba v rabochem dvizhenii Rossii 1914-1917 gg. Moscow, Mysl' Publ., 1972, 304 p. (In Russian)

Hasegawa C. Fevral'skaya revolyuciya]. Kriticheskij slovar' russkoj revolyucii: 1914-1921. St. Petersburg, Nestor-Istoriya Publ., 2014, pp. 60-70. (In Russian)

Haimson L. Problema politicheskoj i social'noj stabil'nosti v gorodskoj Rossii nakanune vojny i revolyucii: sovremennyj vzglyad. Nestor, 2005, no. 3. Mezhdu dvuh revolyucij. 1905-1917. Istochniki, issledovaniya, istoriografiya, pp. 162-192. (In Russian)

Heresh E. Kuplennaya revolyuciya. Tajnoe delo Parvusa. Moscow, OLMA-PRESS; Obrazovanie Publ., 2004, 380 p. (In Russian)

Shlyapnikov A. G. Kanun semnadcatogo goda. Semnadcatyj god. Volume 1. Moscow, Politizdat Publ., 1992a, 383 p. (In Russian)

Shlyapnikov A.G.Kanun semnadcatogo goda. Semnadcatyj god. Volume 2. Moscow, Respublika Publ., 1992b, 496 p. (In Russian)

Yuriy M.F.Central'nyj voenno-promyshlennyj komitet. 1915-1917 gg. Organizacionnoe ustrojstvo $i$ deyatel'nost'. Chernovcy, [S. n.], 1986, 224 p. (In Russian)

Jacobi I. P. Imperator Nikolaj II i revolyuciya. Imperator Nikolaj II i revolyuciya. St. Petersburg, Ed. by The Association of Saint Basil The Grait, 2005, pp. 37-368. (In Russian)

Yakovlev N. N. 1 avgusta 1914 [August 1, 1914]. Moscow, Moskvityanin Publ., 1993, 320 p. (In Russian)

Hasegawa T. The February Revolution. Petrograd, 1917. Seattle; London, University of Washington, 1981, $652 \mathrm{p}$.

Kulikov S. "Revolutions Invariably Come from Above". The Fall of Tsarism Through the Prism of the Elite Circulation Paradigm. Russian Studies in History, 2009, Spring, volume 47, no. 4, pp. 8-39.

Melancon M.Rethinking Russia's February Revolution: Anonymous Spontaneity or Socialist Agency? Pittsburgh, Ed. by The Center for Russian and East European Studies, 2000, 44 p.

Siegelbaum L. The politics of industrial mobilization in Russia, 1914-1917: A study of the war-industries committees. London, Ed. by Macmillan in Association with St. Antony`s College (Oxford), 1983, 312 p.

Received: 28.03 .2017

Accepted: 10.08.2017 